\title{
Local Bond Strength based Lap Splice Length Model of Reinforcing Bars
}

\author{
Hyeon-Jong Hwang
}

\begin{abstract}
Lap splice is a critical issue in the structural performance of Reinforced Concrete members. In the present study, the lap splice length of rebars was theoretically studied. On the basis of the bond behavior in the lap splice, a simplified design method was developed to predict the lap splice length of rebars under tension force. In the proposed method, local bondslip relationship between rebar and concrete was considered. The predicted tensile strength of the splice bars were compared with the 539 existing splice tests results. On the basis of pull-out test results, the proposed model was modified to predict the lap splice length of rebars in the beams using new materials. The predictions agree with the test results.
\end{abstract}

Keywords-Bond strength, Lap splice length, Splice test, Pull-out test

\section{Introduction}

Bond strength between rebar and concrete is critical to the structural performance of the Reinforced Concrete (RC) members. For safe design, current design codes [1-3] require the lap splice length on the basis of a lot of splice test results.

To evaluate bond strength of a rebar, four tests are generally performed: pull-out test, beam-end test, beam anchorage test, and splice test (see Fig. 1). Pull-out test is widely used to evaluate the bond strength of a rebar because of the simplicity of the test. However, pull-out test simulates tensile force of a rebar and compressive force of concrete, which differs actual stress field in most $\mathrm{RC}$ members where tension force is applied to both the rebar and concrete. Thus, to evaluate the lap splice length, ACI $408-03^{2}$ recommends not the pull-out test but the splice test.

Orangun et al. ${ }^{4}$ proposed a lap splice length on the basis of a nonlinear regression analysis of existing splice test results. For better predictions, Zuo and Darwin ${ }^{5}$ additionally considered rebar deformed shape and details, and they used not $\sqrt{ } f_{c}{ }^{\prime}$ but ${ }^{4} \sqrt{ } f_{c}{ }^{\prime}$ for concrete strength on the basis of existing splice test results. Canbay and Frosch ${ }^{6}$ developed a lap splice model based on the split tension cracking failure, which applied directly the effect cover concrete and lateral bars to bond strength.

Because the previous studies proposed empirical equations to define the lap splice length, the existing models can be used within the verified test parameters. Particularly, assuming the uniformly distributed bond strength in the lap splice length, existing design codes overestimate the bond strength as the lap splice length increases, and the predictions show low correlation with the test results.

Hyeon-Jong Hwang

College of Civil Engineering / Hunan University

Changsha, Hunan Province, China

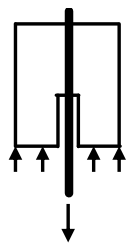

(a) Pull-out specimen

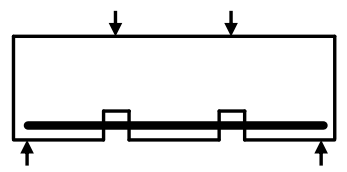

(c) Beam anchorage specimen

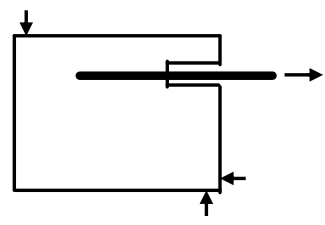

(b) Beam-end specimen

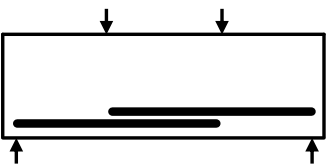

(d) Splice specimen
Figure 1. Bond strength test specimens

In order to more accurately predict the lap splice length, in the present study, the following factors are considered. 1) Local bond strength model based on the relative deformation between rebar and concrete was addressed: both the rebar deformation due to bond-slip and tensile deformation of concrete. 2) On the basis of the bond strength distribution in the lap splice length, two idealized bond strength was distributed: non-damaged bond strength and damaged bond strength. To verify the accuracy, the predicted results were compared with the 539 existing splice test results.

\section{Proposed Lap Splice Length}

\section{A. Simplified Bond Stress Model}

Fig. 2 shows the local bond slip-stress relationship between rebar and concrete. ${ }^{7,8}$ In the lap splice length, concrete is vulnerable to cracks of longitudinal direction due to tension force, which decreases the bond strength. Thus, in the present study, local bond stress model for unconfined concrete subjected to tension force was applied. The peak bond stress $\tau_{u}$ and bond-slip $s_{1}$ are as follows:

$$
\begin{aligned}
\tau_{u} & =0.91 \alpha_{d} \sqrt{f_{c}^{\prime}} \\
s_{1} & =0.3 \sqrt{f_{c}^{\prime} / 30}
\end{aligned}
$$

where $\alpha_{d}=1.1$ for D19 bars below, 1.0 for D22 to D29 bars, and 0.9 for D32 bars above.

Fig. 3 shows a simplified bond strength model. Although the tension forces are applied to the each rebar at the both sides in the lap splice length, lap splice has the bond mechanism similar to that of anchorage of straight bars. Thus, the present study considered the development length model of a rebar, which used fixed boundary conditions in the concrete at the opposite, to conveniently describe the bond stress distribution and the relative deformation 
Proc. of The Second Intl. Conf. On Advances in Civil, Structural and Mechanical Engineering - ACSM 2015 Copyright (C) Institute of Research Engineers and Doctors, USA .All rights reserved. ISBN: 978-1-63248-074-3 doi: 10.15224/ 978-1-63248-074-3-32

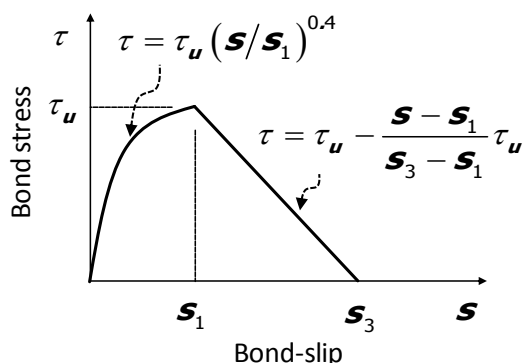

Figure 2. Local bond stress-slip relationship
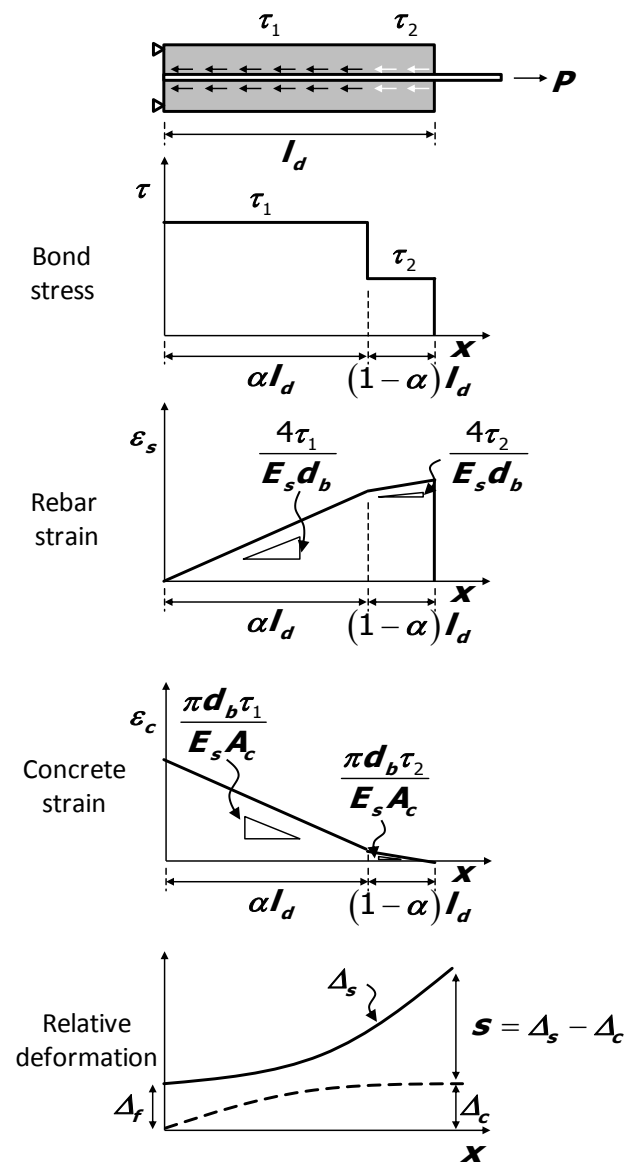

Figure 3. Simplified bond strength model

between rebar and concrete. Note that the lap splice length and development length are not classified (i.e. $l_{s}=l_{d}$ ) in the proposed model. Further, since the relative deformation between rebar and concrete is almost unchanged at $\alpha l_{d}$ due to tensile deformation of concrete, the bond stress $\tau_{1}$ and $\tau_{2}$ are applied to $\alpha l_{d}$ and $(1-\alpha) l_{d}$ as uniformly distributed stress, respectively.

On the basis of the simplified bond stress distribution, strain distributions of rebar and concrete can be estimated (refer to Fig. 3). Note that, in structural design, because large inelastic deformation does not occur in the spliced bars, post-yielding behavior of the rebar was not considered.

$$
\begin{aligned}
& \left(\frac{\pi d_{b}^{2}}{4}\right) \frac{d \sigma_{s}}{d x}=\tau(x)\left(\pi d_{b}\right) \\
& \varepsilon_{s}-\varepsilon_{c}=d s / d x
\end{aligned}
$$

where $d_{b}=$ rebar diameter; $\sigma_{s}=$ tensile strength of the rebar; and $s=$ relative deformation of rebar and concrete due to bond-slip.

Absolute deformation $\Delta_{s}$ of the rebar at the peak strength (i.e. at $\mathrm{x}=l_{d}$ ) can be determined from strain distribution of the rebar.

$$
\begin{aligned}
\Delta_{s} & =\int_{0}^{\alpha l_{d}} \frac{4 \tau_{1}}{E_{s} d_{b}} x d x+\int_{\alpha l_{d}}^{l_{d}}\left[\frac{4 \tau_{1}}{E_{s} d_{b}} \alpha l_{d}+\frac{4 \tau_{2}}{E_{s} d_{b}}\left(x-\alpha l_{d}\right)\right] d x+\Delta_{f} \\
& =\frac{l_{d}^{2}}{E_{s} d_{b}}\left[\left(4 \alpha-2 \alpha^{2}\right) \tau_{1}+\left(2-4 \alpha+2 \alpha^{2}\right) \tau_{2}\right]+\Delta_{f}
\end{aligned}
$$

where $\Delta_{f}=$ absolute deformation of the rebar at zero strain (i.e. at $x=0$ ) regardless of strain distribution of the rebar due to pull-out failure. Thus, in the case of pull-out failure of the rebar, $\Delta_{f}$ increases to maximize the bond strength in the development length $l_{d}$. When the pull-out failure of the rebar does not occur, $\Delta_{f}$ equals to zero. In the present study, $\tau_{1}$ is simplified as $\tau_{u}$ assuming the maximum bond strength in the pull-out failure.

Relative deformation $s$ between rebar and concrete is defined by (4).

$$
s=\Delta_{s}-\Delta_{c}
$$

According to the bond stress distribution in Fig. 3, the relative deformation $s$ should be less than or equal to $s_{l}$ in the development length $\alpha l_{d}$, and $s$ should be greater than $s_{1}$ in the development length (1- $\alpha) l_{d}$ (refer to Fig. 2). Considering that $s$ equals to $s_{l}$ at $x=\alpha l_{d}$ in (5) and (6), $s_{\text {ald }}$ is as follows:

$$
s_{\alpha l_{d}}=\frac{l_{d}^{2}}{E_{s} d_{b}}\left[2 \alpha^{2} \tau_{1}\right]+\Delta_{f}-\Delta_{c} \approx s_{1}
$$

Substituting (7) to (5) and (6),

$$
s=\frac{l_{d}^{2}}{E_{s} d_{b}}\left[\left(4 \alpha-4 \alpha^{2}\right) \tau_{1}+\left(2-4 \alpha+2 \alpha^{2}\right) \tau_{2}\right]+s_{1}
$$

For conservative estimation, when the relative deformation is greater than $s_{1}$, the decreased bond stress $\tau_{2}$ is defined as the bond stress at the maximum relative deformation. Thus, the decreased bond stress $\tau_{2}$ can be defined as the function of the relative deformation $s$ in Fig. 2 .

$$
\tau_{2}=\tau_{1}-\frac{\tau_{1}}{1-s_{1}}\left(s-s_{1}\right)=\frac{\tau_{1}-C_{1} \tau_{1}^{2}\left(4 \alpha-4 \alpha^{2}\right)}{1+C_{1} \tau_{1}\left(2-4 \alpha+2 \alpha^{2}\right)}
$$

where $C_{1}=l_{d}^{2} /\left[\left(1-s_{1}\right) E_{s} d_{b}\right]$.

In the development length $l_{d}$ of a rebar, the maximum tensile stress $f_{s}$ of the rebar is defined as follows:

$$
f_{s}=\frac{4 l_{d}}{d_{b}}\left[\alpha \tau_{1}+(1-\alpha) \tau_{2}\right]
$$

where $\alpha=0.75$ predicts well the test results (see chapter "COMPARISON BETWEEN TEST RESUTLS AND PREDICTIONS". 
Proc. of The Second Intl. Conf. On Advances in Civil, Structural and Mechanical Engineering - ACSM 2015 Copyright (C) Institute of Research Engineers and Doctors, USA .All rights reserved.

ISBN: 978-1-63248-074-3 doi: 10.15224/ 978-1-63248-074-3-32

\section{B. Effect of Cover Concrete and Lateral Bars}

The lap splice length is affected by the effects of split tensile cracks according to cover concrete thickness and spacing of the spliced bars (refer to Fig. 4). Existing design codes considered these effects using same parameters, but the different coefficients were used. In the present study, the method proposed by ACI 408R-032 was used.

For ACI 408R-03

$$
\begin{aligned}
& \tau_{1}=0.91 \alpha_{d} \sqrt{f_{c}^{\prime}}\left[\frac{\left(c w+K_{t r}\right) / d_{b}}{2.5}\right] \\
& \left(c w+K_{t r}\right) / d_{b} \leq 4.0 \\
& w=0.1\left(c_{\max } / c_{\text {min }}\right)+0.9 \leq 1.25 \\
& K_{t r}=6 \sqrt{f_{c}^{\prime}} t_{d} A_{t r} /\left(s_{t} n\right) \\
& t_{d}=0.03 d_{b}+0.22
\end{aligned}
$$

where $c=c_{\min }+d_{b} / 2 ; c_{\max }=\max \left(c_{b}, c_{s}\right) ; c_{\min }=\min \left(c_{b}, c_{s}\right) ; c_{\mathrm{s}}=$ $\min \left(c_{s o}, c_{s i}+6.4\right) ; c_{b}=$ thickness of the bottom cover concrete; $c_{s o}=$ thickness of the side cover concrete; $c_{s i}=$ one-half of the center-to-center bar spacing; $A_{t r}=$ total cross-sectional area of transverse bars within spacing $s_{t}$ that cross the potential plane of splitting; $n=$ the number of bars being developed or spliced along the splitting plane; and $s_{t}=$ center-to-center distance of the transverse bars. Note that the coefficient of the cover concrete and lateral bars by ACI $408 \mathrm{R}-03^{2}$ is divided into 2.5 , which is same to the bond strength by ACI $318-11^{1}$ before pull-out failure.

\section{Comparison Between Test Results and Predictions}

Table 1 presents the test parameters of existing splice specimens. For total 539 specimens, the splice length $l_{s}$ was 76 to $2311 \mathrm{~mm}$ [3.0 to $91.0 \mathrm{in}$ ], the rebar diameter $d_{b}=9.5$ to $43.0 \mathrm{~mm}$ [0.4 to $1.7 \mathrm{in}$ ], the concrete strength $f_{c}{ }^{\prime}$ was 12.6 to $113.0 \mathrm{MPa}$ [1.8 to $16.4 \mathrm{ksi}$ ], and yield strength of the rebar $f_{y}$ was 345 to $830 \mathrm{Mpa}$ [50.0 to $120.3 \mathrm{ksi}] .^{9-25}$ Table 2 compares the predictions by the existing design models and proposed model to the test results.

Fig. 5 compares the tensile strength of the rebar predicted by the existing design codes and proposed model to the test results according to the ratio of the splice length to rebar diameter. ACI $318-11^{1}$ underestimated the tensile strength of the rebars $f_{s}$, which causes the conservatively designed lap splice length $l_{s}$. Particularly, the existing design codes overestimated the tensile strength of the rebars $f_{s}$ as the lap splice length ratio $l_{s} / d_{b}$ increases. On the other hand, ACI $408 \mathrm{R}-03^{2}$ (average $=1.00$, and COV $=0.151$ ) and the proposed model using the coefficient of ACI 408R-03 ${ }^{2}$ (average $=1.00$, and COV $=0.153$ ) predicted $f_{\text {test }} / f_{s}=1.0$ in

\begin{tabular}{|c|c|c|c|c|c|}
\hline Specimens & $\begin{array}{l}\text { \# of } \\
\text { tests }\end{array}$ & $l_{s} / d_{b}$ & $f_{c}^{\prime}(\mathbf{M P a})$ & $f_{y}(\mathrm{MPa})$ & $\left(c w+K_{t r}\right) / d_{b}$ \\
\hline Chinn et al. $^{9}$ & 40 & $9.3-31.9$ & $21.8-51.6$ & $393-545$ & $1.51-3.09$ \\
\hline Chamberlin $^{10}$ & 18 & $6.0-24.0$ & $30.2-32.0$ & 345 & $2.63-2.88$ \\
\hline Ferguson and Thompson ${ }^{11}$ & 42 & $18.0-48.0$ & $16.4-41.1$ & $566-604$ & $1.74-4.00$ \\
\hline Ferguson and Breen $^{12}$ & 35 & $18.0-80.0$ & $12.6-38.8$ & $428-676$ & $1.89-2.78$ \\
\hline Ferguson and Bricer ${ }^{13}$ & 32 & $23.4-60.3$ & $16.9-30.0$ & $449-483$ & $1.25-2.13$ \\
\hline Thompson et al. ${ }^{14}$ & 25 & $14.2-36.0$ & $17.4-32.5$ & $384-464$ & $1.33-3.16$ \\
\hline Zekany et al. $^{15}$ & 24 & $14.2-15.6$ & $25.5-39.3$ & $415-433$ & $1.92-2.43$ \\
\hline Choi et al. ${ }^{16}$ & 10 & $16.0-19.2$ & $37.0-41.5$ & $435-489$ & $1.92-2.31$ \\
\hline Azizinamini et al. ${ }^{17}$ & 18 & $9.2-56.8$ & $35.1-104.3$ & $489-537$ & $1.48-1.50$ \\
\hline Hester et al. ${ }^{18}$ & 32 & $10.0-22.8$ & $34.7-44.5$ & $440-499$ & $2.36-4.00$ \\
\hline Rezansoff et al. ${ }^{19}$ & 15 & $11.9-37.6$ & $25.0-28.2$ & $445-475$ & $1.78-3.52$ \\
\hline Azizinamini et al. ${ }^{20}$ & 12 & $28.4-56.8$ & 75.2-113.9 & $489-509$ & $1.48-2.34$ \\
\hline Darwin et al. $^{21}$ & 25 & $16.0-28.4$ & $26.3-36.2$ & $445-538$ & $2.17-3.74$ \\
\hline Azizinamini et al. ${ }^{22}$ & 70 & $9.2-56.8$ & $35.1-113.9$ & $489-537$ & $1.50-4.00$ \\
\hline Zuo and Darwin ${ }^{23}$ & 65 & $16.0-40.0$ & $29.3-108.0$ & $435-556$ & $1.38-3.53$ \\
\hline Seliem et al. ${ }^{24}$ & 64 & $24.0-70.3$ & $28.0-70.3$ & 830 & $1.68-4.00$ \\
\hline Choi et al. ${ }^{25}$ & 12 & 29.4-60.1 & $24.7-55.3$ & $650-720$ & $1.80-3.65$ \\
\hline Total & 539 & $6.0-80.0$ & $12.6-113.9$ & $345-830$ & $1.25-4.00$ \\
\hline
\end{tabular}
most of specimens.

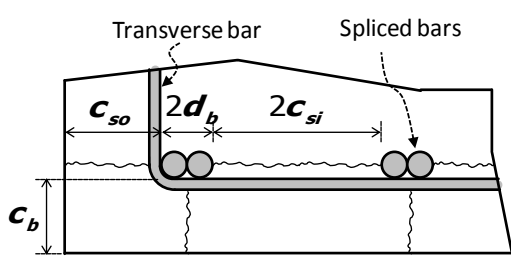

\begin{tabular}{|c|c|c|c|c|}
\hline Specimens & $\begin{array}{c}f_{\text {test }} / f_{s} \\
(\mathrm{ACI} 318- \\
11)\end{array}$ & $\begin{array}{c}f_{\text {test }} / f_{s} \\
\text { (ACI 408R- } \\
03)\end{array}$ & $\begin{array}{c}f_{\text {test }} / f_{s} \\
\text { (Eurocode } \\
2)\end{array}$ & $\begin{array}{c}f_{\text {test }} / f_{s} \\
\text { (Prediction) }\end{array}$ \\
\hline Chinn et al. ${ }^{9}$ & $0.83-2.65$ & $0.69-1.31$ & $0.83-1.91$ & $0.68-1.54$ \\
\hline Chamberlin $^{10}$ & $0.96-2.72$ & $0.62-1.05$ & $0.96-2.77$ & $0.81-1.57$ \\
\hline Ferguson and Thompson ${ }^{11}$ & $1.27-2.87$ & $0.65-1.44$ & $1.00-2.15$ & $0.59-1.34$ \\
\hline Ferguson and Breen ${ }^{12}$ & $0.99-2.43$ & $0.79-1.33$ & $0.90-1.70$ & $0.74-1.33$ \\
\hline Ferguson and Bricer ${ }^{13}$ & $0.61-2.01$ & $0.58-1.13$ & $0.55-1.28$ & $0.55-1.22$ \\
\hline Thompson et al. ${ }^{14}$ & $1.36-2.37$ & $0.82-1.19$ & $0.94-1.86$ & $0.87-1.36$ \\
\hline Zekany et al. ${ }^{15}$ & $1.41-2.03$ & $0.81-1.24$ & $1.12-1.60$ & $0.82-1.26$ \\
\hline Choi et al. ${ }^{16}$ & $1.21-1.77$ & $0.73-1.24$ & $0.83-1.50$ & $0.79-1.07$ \\
\hline Azizinamini et al. ${ }^{17}$ & $0.90-1.72$ & $0.75-1.04$ & $0.66-0.96$ & $0.66-1.09$ \\
\hline Hester et al. ${ }^{18}$ & $1.15-2.35$ & $0.73-1.32$ & $0.90-1.85$ & $0.58-1.27$ \\
\hline Rezansoff et al. ${ }^{19}$ & $1.59-2.18$ & $0.86-1.22$ & $1.08-1.60$ & $0.92-1.10$ \\
\hline Azizinamini et al. ${ }^{20}$ & $0.93-1.14$ & $0.77-1.13$ & $0.66-1.13$ & $0.66-1.13$ \\
\hline Darwin et al. ${ }^{21}$ & $1.18-2.09$ & $0.83-1.16$ & $1.01-1.68$ & $0.72-1.03$ \\
\hline Azizinamini et al. ${ }^{22}$ & $0.90-1.72$ & $0.74-1.12$ & $0.66-1.12$ & $0.66-1.12$ \\
\hline Zuo and Darwin ${ }^{23}$ & $1.09-2.57$ & $0.87-1.41$ & $0.65-1.73$ & $0.71-1.16$ \\
\hline Seliem et al. ${ }^{24}$ & $0.76-2.26$ & $0.76-1.49$ & $0.56-1.52$ & $0.59-1.29$ \\
\hline Choi et al. ${ }^{25}$ & $0.95-1.67$ & $0.81-1.15$ & $0.77-1.45$ & $0.77-1.00$ \\
\hline Total & $0.61-2.87$ & $0.58-1.49$ & $0.55-2.77$ & $0.55-1.57$ \\
\hline Average & 1.50 & 1.00 & 1.14 & 1.00 \\
\hline COV. & 0.267 & 0.151 & 0.257 & 0.153 \\
\hline
\end{tabular}

Figure 4. Cross-section of splice specimen

TABLE I. Test Parameters of EXISTING SPlice TeSt SPECIMENS

TABLE II. COMPARISON BETWEEN TEST RESUlts AND PREDICTIONS 
Proc. of The Second Intl. Conf. On Advances in Civil, Structural and Mechanical Engineering - ACSM 2015 Copyright @ Institute of Research Engineers and Doctors, USA .All rights reserved. ISBN: 978-1-63248-074-3 doi: 10.15224/ 978-1-63248-074-3-32
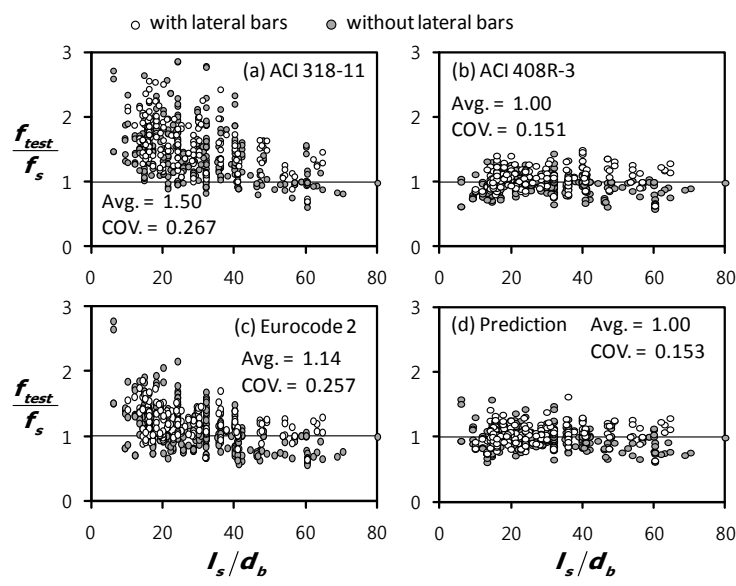

Figure 5. Reinforcing bar stress ratio of specimens according to lap splice length ratio

Note that ACI $408 \mathrm{R}-03^{2}$ and the proposed model did not use a safety factor. On the basis of the comparison between predictions and test results, tensile force $f_{s}$ of rebar and splice length $l_{s}$ in the proposed model using $\alpha=0.75$ can be simplified as follows.

$$
\begin{aligned}
& f_{s}=\frac{l_{d}}{d_{b}}\left[3 \tau_{1}+\tau_{2}\right] \\
& l_{d}=\frac{f_{y} d_{b}}{3 \tau_{1}+\tau_{2}} \\
& \tau_{1}=0.91 \alpha_{d} \sqrt{f_{c}^{\prime}}\left[\frac{\left(c w+K_{a t r}\right) / d_{b}}{2.5}\right] \\
& \tau_{2}=\frac{8 \tau_{1}-6 C_{1} \tau_{1}^{2}}{8+C_{1} \tau_{1}}
\end{aligned}
$$

where $C_{1}=l_{d}^{2} /\left[\left(1-0.3 \sqrt{f_{c}^{\prime} / 30}\right) E_{s} d_{b}\right]$.

\section{Conclusions}

In the present study, a simplified model was developed to predict the lap splice length using the local bond strength model according to the relative deformation between rebar and concrete. On the basis of the relative deformation and local bond strength model, bond strength distribution was simplified to two equivalent bond strength: non-damaged bond strength, and damaged bond strength. For the effects of cover concrete and lateral bars, the ACI 408R-03 model was used. The validity of the proposed method was verified using the 539 existing lap splice test results. Existing design codes overestimated bond strength as the lap splice length increases. On the other hand, the proposed method predicted the tensile strength of the spliced bars with reasonable precision.

\section{A. Authors and Affiliations}

1) Hyeon-Jong Hwang is an Assistant Professor in the College of Civil Engineering at Hunan University, China. He received his $B E, M S$, and $P h D$ in architectural engineering from Seoul National University. His research interests include inelastic analysis and the seismic design of $R C$ and composite structures.

\section{Acknowledgment}

This research was financially supported by the Youth Program of Hunan University. The authors are grateful to the authorities for their support.

\section{References}

[1] ACI Committee 318, "Building Code Requirements for Structural Concrete and Commentary", American Concrete Institute, Farmington Hills, MI, 2011, 503 pp.

[2] ACI Committee 408, "Bond and Development of Straight Reinforcing Bars in Tension (ACI 408R-03)," American Concrete Institute, Farmington Hills, MI, 2003, 49 pp.

[3] British Standards, "Eurocode 2: Design of Concrete Structures", BS EN 1992-1:2004, 2004, 225 pp.

[4] C.O. Orangun, J.O. Jirsa, and J.E. Breen, "A Reevaluation of Test Data on Development Length and Splices," ACI JOURNAL, Proceedings, vol. 74, no. 3, 1977, pp. 114-122.

[5] J. Zuo, and D. Darwin, "Splice Strength of Conventional and High Relative Rib Area Bars in Normal and High-Strength Concrete," ACI Structural Journal, vol. 97, no. 4, 2000, pp. 630-641.

[6] E. Canbay, and R.J. Frosch, "Bond Strength of Lap-Spliced Bars," ACI Structural Journal, vol. 102, no. 4, 2005, pp. 605-614.

[7] R. Eligehausen, E.P. Popov, and V.V. Bertero, "Local Bond StressSlip Relationships of Deformed Bars under Generalized Excitations," Earthquake Engineering Research Council Rep. No. 82/23, Univ. of California, Berkeley, Calif., 1983, 169 pp.

[8] V. Ciampi, R. Eligehausen, V.V. Bertero, and E.P. Popov, "Analytical Model for Concrete Anchorages of Reinforcing Bars under Generalized Excitations," Earthquake Engineering Research Council Rep. No. 83/23, Univ. of California, Berkeley, Calif., 1982.

[9] J. Chinn, P.M. Ferguson, and J.N. Thompson, "Lapped Splices in Reinforced Concrete Beams," ACI JOURNAL, Proceedings vol. 52, no. 2, 1955, pp. 201-213.

[10] S.J. Chamberlin, "Spacing of Spliced Bars in Beams," ACI JOURNAL, Proceedings, vol. 54, no. 8, 1958, pp. 689-698.

[11] P.M. Ferguson, and J.N. Thompson, "Development Length for Large High Strength Reinforcing Bars in Bond," ACI JOURNAL, Proceedings, vol. 59, no. 7, 1962, pp. 887-922.

[12] P.M. Ferguson, and J.E. Breen, "Lapped Splices for High-Strength Reinforcing Bars,” ACI JOURNAL, Proceedings, vol. 62, no. 9, 1965, pp. 1063-1078.

[13] P.M. Ferguson, and A. Briceno, "Tensile Lap Splices-Part 1: Retaining Wall Type, Varying Moment Zone," Research Report No. 113-2, Center for Highway Research, The University of Texas at Austin, 1969.

[14] M.A. Thompson, J.O. Jirsa, J.E. Breen, and D.F. Meinheit, "The Behavior of Multiple Lap Splices in Wide Sections," Research Report No. 154-1, Center for Highway Research, The University of Texas at Austin, 1975, 75 pp.

[15] A.J. Zekany, S. Neumann, J.O. Jirsa, and J.E. Breen, "The Influence of Shear on Lapped Splices in Reinforced Concrete," Research Report No. 242-2, Center for Transportation Research, Bureau of Engineering Research, The University of Texas at Austin, 1981, 88 pp.

[16] O.C. Choi, H. Hadje-Ghaffari, D. Darwin, and S.L. McCabe, "Bond of Epoxy-Coated Reinforcement: Bar Parameters," ACI Materials Journal, vol. 88, no. 2, 1991, pp. 207-217.

[17] A. Azizinamini, M. Stark, J.J. Roller, and S.K. Ghosh, "Bond Performance of Reinforcing Bars Embedded in High-Strength Concrete," ACI Structural Journal, vol. 90, no. 5, 1993, pp. 554-561.

[18] C.J. Hester, S. Salamizavaregh, D. Darwin, and S.L. McCabe, "Bond of Epoxy-Coated Reinforcement: Splices," ACI Structural Journal, vol. 90, no. 1, 1993, pp. 89-102.

[19] T. Rezansoff, A. Akanni, and B. Sparling, "Tensile Lap Splices under Static Loading: A Review of the Proposed ACI 318 Code Provisions," ACI Structural Journal, vol. 90, no. 4, 1993, pp. 374-384.

[20] A. Azizinamini, M. Chisala, and S.K. Ghosh, "Tension Development Length of Reinforcing Bars Embedded in High-Strength Concrete," Engineering Structures, vol. 17, no. 7, 1995, pp. 512-522. 
[21] D. Darwin, M.L. Tholen, E.K. Idun, and J. Zuo, "Splice Strength of High Relative Rib Area Reinforcing Bars,” ACI Structural Journal, vol. 93, no. 1, 1996, pp. 95-107.

[22] A. Azizinamini, R. Pavel, E. Hatfield, and S.K. Ghosh, "Behavior of Spliced Reinforcing Bars Embedded in High Strength Concrete," ACI Structural Journal, vol. 96, no. 5, 1999, pp. 826-835.

[23] J. Zuo, and D. Darwin, "Splice Strength of Conventional and High Relative Rib Area Bars in Normal and High-Strength Concrete," ACI Structural Journal, vol. 97, no. 4, 2000, pp. 630-641.

[24] H.M. Seliem, A. Hosny, S. Rizkalla, P. Zia, M. Briggs, S. Miller, D. Darwin, J. Browning, G.M. Glass, K. Hoyt, K. Donnelly, and J.O. Jirsa, "Bond Characteristics of ASTM A1035 Steel Reinforcing Bars," ACI Structural Journal, vol. 106, no. 4, 2009, pp. 530-539.

[25] W.S. Choi, H.G. Park, L. Chung, and J.K. Kim, "Experimental Study for Class B Lap Splice of $600 \mathrm{MPa}(87 \mathrm{ksi})$ Reinforcing Bars," ACI Structural Journal, vol. 111, no. 1, 2014, pp. 49-58.

About Author (s):

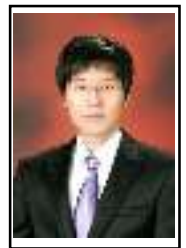

[Lap splice is a critical issue in RC members. In order to more accurately predict the lap splice length, not empirical equation but mechanics based simplified lap splice model is needed.] 